\title{
Perception of teratogenic and foetotoxic risk by health professionals: a survey in Midi-Pyrenees area
}

Christine DAMASE-MICHEL, Juliette PICHEREAU, Atul PATHAK, Isabelle LACROIX, Jean Louis MONTASTRUC.

\begin{abstract}
${ }^{*}$
Counselling or prescribing drugs during pregnancy requires health professionals to assess risk/benefit ratio for women and their baby. A misperception of the risk may lead to inappropriate decisions for pregnancy outcomes.

The aim of the present study was to assess teratogenic and/or foetotoxic risk perception of common medications by general practitioners (GPs) and community pharmacists (CPs) from the MidiPyrenees area.

Methods: 103 GPs and 104 CPs were interviewed. For 21 given drugs, a visual-analogue scale was used to evaluate the risk to give birth to a malformed infant if the mother had taken the drug during first trimester of pregnancy. For 9 drugs, health professionals had to say if they thought there was a potential foetotoxic and/or neonatal risk when drugs were administered during late pregnancy. Results: $97 \%$ and $91 \%$ of GPs and CPs respectively thought that isotretinoin and thalidomide are teratogenic and more than $80 \%$ thought that amoxicillin and acetaminophen are safe in early pregnancy. However, $19 \%$ of the GPs and $33 \%$ of CPs answered there were no teratogenic risk for valproate. Around $11 \%$ of both GPs and CPs said that warfarin was safe during pregnancy. For $22 \%$ of GPs and for $13 \%$ and $27 \%$ of CPs respectively, ibuprofen and enalapril were safe on late pregnancy. For each drug, mean value of perceived teratogenic risk by health professionals was higher than values that can be found in scientific references. Concerning isotretinoin, thalidomide and metoclopramide, perceived teratogenic risk was higher for CPs.
\end{abstract}

\footnotetext{
"Christine DAMASE-MICHEL. PharmD PhD. Department of Pharmacology, Research Unit of

Pharmacoepidemiology, Faculty of Medicine, University of Toulouse III Paul Sabatier, (France).

Juliette PICHEREAU. PharmD. Department of

Pharmacology, Research Unit of Pharmacoepidemiology, Faculty of Medicine, University of Toulouse III Paul Sabatier, (France).

Atul PATHAK. MD PhD. Department of Pharmacology, Research Unit of Pharmacoepidemiology, Faculty of Medicine, University of Toulouse III Paul Sabatier, (France).

Isabelle LACROIX. Pharm D. Department of

Pharmacology, Research Unit of Pharmacoepidemiology, Faculty of Medicine, University of Toulouse III Paul Sabatier, (France).

Jean Louis MONTASTRUC. MD PhD. Department of Pharmacology, Research Unit of Pharmacoepidemiology, Faculty of Medicine, University of Toulouse III Paul Sabatier, (France).
}

Conclusion: These data show that the potential teratogenic and foetotoxic risk of several commonly used drugs is unknown by health professionals. Conversely, GPs and CPs who think that a risk exists, overestimate it. This misperception can lead to inappropriate decisions for pregnancy outcomes.

Keywords: Teratogens. Health Knowledge, Attitudes, Practice. France.

\section{PERCEPCIÓN DEL RIESGO TERATOGÉNICO Y FETOTÓXICO POR LOS PROFESIONALES DE LA SALUD: ESTUDIO EN EL AREA DE MIDI-PYRENEES}

\section{RESUMEN}

Aconsejar o prescribir medicamentos durante el embarazo requiere que los profesionales de la salud evalúen la relación riesgo/beneficio para la mujer y su bebé. Una mala percepción del riesgo, puede llevar a decisiones inapropiadas para los resultados del embarazo.

El objetivo del presente estudio fue evaluar la percepción del riesgo teratogénico y/o fetotóxico de medicamentos frecuentes por médicos generales (MG) y farmacéuticos comunitarios (FC) de la región de Midi-Pyrenees.

Métodos: Se entrevistó a 103 MG y 104 FC. Se utilizó una escala visual analógica EVA para evaluar el riesgo de dar a luz un niño malformado si la madre había usado el medicamento durante el primer trimestre de embarazo. Para 9 medicamentos, los profesionales tenían que decir si pensaban que había un riesgo teratogéncio y/o fetotóxico cuando se administraban los medicamentos al final del embarazo.

Resultados: el $97 \%$ y el $91 \%$ de los MG y FC respectivamente pensaron que la isotretinoína y la talidomida eran teratogénicos y más del $80 \%$ pensó que la amoxicilina y el paracetamol eran seguros al principio del embarazo. Sin embargo, el 19\% de los MG y el 33 de los FC respondió que no había riesgo teratogénico en el valproato. Cerca del $11 \%$ tanto de MG y de FC dijo que la warfarina era segura durante el embarazo. Para el 22\% de los MG y para $13 \%$ y $27 \%$ de FC el ibuprofeno y el enalaprilo eran seguros al final del embarazo, respectivamente. Para cada medicamento, el valor medio del riesgo teratogénico para los profesionales era superior a los valores encontrados en la literatura. Relativamente a la isotretinoína, talidomina y metoclopramida, el riesgo percibido era superior para los FC. 
Conclusión: Estos datos muestran que el posible riesgo teratogénico y fetotóxico de varios medicamentos frecuentemente utilizados no es conocido por los profesionales de la salud. Por el contrario, los MG y FC que piensan que existe riesgo, lo sobre-estiman. Esta mala interpretación puede conducir a decisiones inapropiadas en el embarazo.

Palabras clave: Teratógenos. Conocimiento, actitudes y práctica sanitarias. Francia.

\section{INTRODUCTION}

After thalidomide had been marketed in the 1960s, people became aware of the teratogenic risk of drug used during pregnancy. Due to this event and several others (diethylstilbestrol in the 70s and retinoids in the $80 \mathrm{~s}$ ), drug prescription for a pregnant woman induces anxiety, not only for woman, but, also for health professionals. However, drug prescription in pregnancy is common. Prescribing or counselling drugs during pregnancy requires health professionals to assess a benefit/risk ratio not only for woman herself but also for her baby. Thus, a right evaluation of the risk is essential. A lack of knowledge of teratogenic or foetotoxic properties of a drug may enhance the risk of neonatal malformation or disease. Conversely, if the risk of malformation is overestimated, this may lead to disadvantageous decisions for the woman and her intended infant. Moreover, previous studies from our group have found differences in the perception of risks according to drugs in a same pharmacological class ${ }^{2}$ or to health professionals. ${ }^{2,3}$

The aim of the present study was to evaluate the knowledge of medication risk during pregnancy of general practitioners (GP) and community pharmacists (CP) of Midi-Pyrenees area.

\section{METHODS}

General practitioners (GPs) and community pharmacists (CPs) of Midi-Pyrenees area were interviewed at the beginning of continuous courses, the subjects of which were different from drug and pregnancy. They were asked to answer individually and spontaneously to the questionnaire. All questionnaires were collected at the end of the session. Nobody refused to participate.

The questionnaire contained two parts. The first one concerned the teratogenic risk. The respondents were asked to indicate whether they think there is a risk when a given drug is taken on the first trimester of pregnancy; the possible answers were "yes", "no" or "no idea". Moreover, for each drug, health professionals were asked to put a mark along the line of a visual analogue scale (VAS) to indicate their estimation of the potential teratogenic risk of the drug. The question was: "a drug may affect formation and development of the organs of the embryo when it is taken on the first trimester of pregnancy. For each drug below, do you think there is a malformation risk? Put a harrow on the scale from $0 \%$ to $100 \%$ to indicate the value of teratogenic risk. (0\%: no risk, $100 \%$ : all neonates have a birth defect")". The VAS measured $20 \mathrm{~cm}$ and was delimited by 2 vertical lines, from $0 \%$ (no malformation) to $100 \%$ (all the newborns were malformed). The VAS was longer than usual in order to permit a more precise evaluation of the risk value for small levels. A list of about 20 drugs was established including common medicine of different pharmacotherapeutic classes: antibiotic, analgesic, anti-inflammatory, anxiolytics, antiepileptics, antipsychotics, contraceptives, anti-emetics, antiacid....The non proprietary name and the trade mark were given for each drug.

The second part of the questionnaire concerned the occurrence of neonatal pathology due to drug intake on late pregnancy. For 9 drugs, the respondent had to answer by "yes", "no" or "I don't know" to the following question: "do you think that a neonatal pathology could occur with this drug when it is used on late pregnancy?"

The questionnaire has been completed by 103 GPs (64 men, 25 women and 14 who did not specify their gender) and by 104 CPs (16 men and 88 women). One GP did not complete the second part of a questionnaire.

The level of the risk was quantified by measuring the distance in millimetres from the $0 \%$ to the mark indicated by the health professional on the VAS. The mean and standard error of the mean values of the estimated risk were calculated for each group and drug. To determinate abstention rate, for each drug, we computed the percentage of CPs or GPs who did not put a mark on the corresponding line. Then, we calculate the mean value of these percentages for the 21 drugs. The "true" value of the risk was evaluated from published studies and reference sources (books ${ }^{4}$, on line data bases ${ }^{5,6}$ ). To compare the results, a chi-scare test was performed. With a value of $p<0.05$, the differences were considered as statistically significant.

\section{RESULTS}

\section{Teratogenic risk of drugs}

(Table 1) The percentage of health professionals giving a positive answer about the existence of a teratogenic risk ranged from $6 \%$ for amoxicillin and acetaminophen to $97 \%$ for isotretinoin. Drugs considered as dangerous by more than $50 \%$ of health professionals were the following: isotretinoin, thalidomide, gentamicine, lithium, norfloxacine, ibuprofene, aspirine, cyproterone + ethynylestradiol, carbamazepin, warfarin, oral contraceptive and erythromycin. Acetaminophen, amoxicillin, domperidone and metoclopramide were mainly considered as safe. $11 \%$ of health professionals thought there is no risk with warfarin and $30 \%$ did not know. $26 \%$ answered that there is no risk with valproate and $23 \%$ had no idea. Nearly $17 \%$ thought that there is no risk with carbamazepine and $25 \%$ did not give an opinion. Concerning lithium, $6 \%$ answered that there is no risk and more 
than $20 \%$ had no opinion. $2 \%$ and nearly $6 \%$ of health professionals had no idea about the teratogenic risk of isotretinoin and thalidomide respectively.

\begin{tabular}{|c|c|c|c|c|}
\hline & $\begin{array}{l}\text { Yes } \\
(\%)\end{array}$ & $\begin{array}{l}\text { No } \\
(\%)\end{array}$ & $\begin{array}{c}\text { No } \\
\text { opinion } \\
(\%)\end{array}$ & $\begin{array}{c}\text { Inconsistent } \\
(\%)\end{array}$ \\
\hline Amoxicillin & 6.3 & 86.0 & 2.9 & 4.8 \\
\hline Acetaminophen & 6.3 & 87.0 & 1.0 & 5.7 \\
\hline Domperidone & 21.3 & 61.8 & 10.6 & 6.3 \\
\hline Métoclopramide & 22.7 & 60.9 & 10.1 & 6.3 \\
\hline Ranitidine & 24.2 & 38.2 & 35.7 & 1.9 \\
\hline Bromazepam & 37.7 & 34.3 & 23.2 & 4.8 \\
\hline LS COC & 40.1 & 35.7 & 22.3 & 1.9 \\
\hline Corticoides & 46.9 & 32.9 & 17.4 & 2.8 \\
\hline Valproate & 49.8 & 26.1 & 23.7 & 0.4 \\
\hline Erythromycin & 50.2 & 30.0 & 17.4 & 2.4 \\
\hline SS COC & 51.7 & 26.1 & 20.8 & $\overline{1.4}$ \\
\hline Warfarin & 57.5 & 11.1 & 30.0 & 1.4 \\
\hline Carbamazepine & 58.0 & 16.9 & 25.1 & 0 \\
\hline Cyprotérone+EE & 62.8 & 12.6 & 22.7 & 1.9 \\
\hline Aspirin & 65.2 & 26.6 & 6.8 & 1.4 \\
\hline Ibuprofen & 68.6 & 20.8 & 9.2 & 1.4 \\
\hline Norfloxacin & 70.5 & 10.6 & 17.5 & 1.4 \\
\hline Lithium & 72.0 & 6.3 & 21.3 & 0.4 \\
\hline Gentamicin & 74.9 & 4.8 & 19.8 & 0.5 \\
\hline Thalidomide & 94.2 & 0 & 5.8 & 0 \\
\hline Isotretinoin & 97.1 & 0 & 2.4 & 0.5 \\
\hline
\end{tabular}

There were statistically different responses between GPs and CPs for 12 drugs. 67\% of the GPs have associated valproate with a teratogenic risk when CPs opinion is controversial (33\% positive, $33 \%$ negative and $34 \%$ no idea). Concerning Bromazepam, $47 \%$ of the GPs thought there is a teratogenic risk and only $29 \%$ of the CPs had this opinion. Concerning other drugs for which there is a difference in risk knowledge (warfarin, lithium, gentamicin, norfloxacine, ibuprofene, carbamazepine, erythromycin, ranitidine, metoclopramide and domperidone), GPs generally gave more clear-cut responses than CPs ("no opinion" was more frequent for CPs: $26 \%$ for CP versus $14 \%$ for GPs).

\section{Risk of neonatal disease}

(Table 2) A majority of health professionals answered that codein, aspirin, ibuprofen, warfarin and bromazepam, are not safe if they are consumed on late pregnancy and more than $90 \%$ of them thought that acetaminophen and amoxicillin are safe. However, $16 \%, 17 \%$ and $22 \%$ answered that there is no foetal and/or neonatal risk when aspirin, ibuprofen and enalapril are administered on late pregnancy. More than $30 \%$ of the subjects had no idea about the risk of neonatal pathology if enalapril or valproate are administered close to the end of pregnancy.

Compared to the GPs the pharmacist had a worse knowledge of neonatal risk with valproate. $62 \%$ of GPs though that valproate is not safe vs. $30 \%$ of the CPs.

\begin{tabular}{l}
\hline $\begin{array}{l}\text { Table 2: Responses given by healthcare professionals } \\
\text { about the risk of neonatal pathology with a given drug } \\
\text { on late pregnancy. }\end{array}$ \\
\hline
\end{tabular}

\section{Teratogenic risk assessment}

Table 3 indicates the mean values of the perceived risk estimated by health professionals. For all drugs, the teratogenic risk was overestimated when compared to values from the literature. The estimation of the risk ranged from $13 \%$ for acetaminophen to $92 \%$ for Thalidomide. $51 \%$ of CPs did not indicate a mark on the VAS (vs $19 \%$ of the GPs). When GPs and CPs are compared, the perception of teratogenic risk was statistically higher for CPs $(p<0,05)$ for isotretinoin (CPs $=94 \%$; GPs $=85 \%)$, thalidomide (CPs $=94 \%$, GPs $=90 \%)$ and metoclopramide (CPs=45\%, GPs=23\%).

Table 3: Mean value of the perceived teratogenic risk by 207 healthcare professionals of Midi-Pyrenees area.

\begin{tabular}{|l|r|r|}
\hline \multirow{2}{*}{} & \multicolumn{2}{|c|}{ Risk (5) } \\
\cline { 2 - 3 } & $\begin{array}{c}\text { perceived } \\
\text { Mean (SD) }\end{array}$ & \multicolumn{1}{c|}{ literature } \\
\hline Aspirin & $45.2(4.5)$ & 2 \\
\hline Acetaminophen & $13.6(4.5)$ & 2 \\
\hline Ibuprofen & $44.5(4.5)$ & 2 \\
\hline Corticosteroids & $40.7(4.9)$ & 2 \\
\hline Erythromycin & $50.3(6.1)$ & 2 \\
\hline Gentamicin & $54.9(5.4)$ & 2 \\
\hline Amoxicilline & $20.1(8.2)$ & 2 \\
\hline Norfloxacin & $46.3(4.7)$ & 2 \\
\hline Bromazepam & $37.6(5.1)$ & 2 \\
\hline Ranitidine & $35.4(5.0)$ & 2 \\
\hline Métoclopramide & $28.0(5.1)$ & 2 \\
\hline Dompéridone & $24.3(5.7)$ & 2 \\
\hline SS COC & $44.1(7.1)$ & 2 \\
\hline LS COC & $40.6(5.6)$ & 2 \\
\hline Cyproterone+EE & $48.8(4.8)$ & 2 \\
\hline Carbamazepine & $45.4(4.5)$ & 6 \\
\hline Valproate & $41.8(6.9)$ & 10 \\
\hline Lithium & $55.8(5.4)$ & 12 \\
\hline Isotretinoin & $89.0(5.3)$ & 25 \\
\hline Warfarin & $58.7(5.3)$ & 30 \\
\hline Thalidomide & $91.7(7.5)$ & 50 \\
\hline LS COC: Low Strength combined oral contraceptives, \\
$\begin{array}{l}\text { SS COC: Standard } \\
\text { contraceptives. }\end{array}$ & strength combined & oral \\
A value of 2\% does & not differ from the rate of \\
malformation in general population. & \\
\hline & \multicolumn{2}{|c|}{ con } \\
\hline
\end{tabular}

\section{DISCUSSION}

The present study evaluates teratogenic and/or foetotoxic risk perception of common medications by GPs and CPs of Midi-Pyrenees area. It shows that the potential risks for the embryo or the foetus of several commonly used drugs is unknown by a 
lot of health professionals. In addition, when it is known, teratogenic risk is overestimated.

The lack of opinion and false answers observed in the responses to the questionnaire suggest a lack of knowledge on drug use in pregnancy. Such a result has already been observed by our group in an opinion survey of CPs about drug counselling in pregnancy. It has been shown that CPs do not always give appropriate advice to pregnant women. ${ }^{7}$ This could be explained by several points. First, initial training about drug use in pregnancy is insufficient during pharmaceutical and medical studies (2h within 6 years for CPs and 3.5h within 9 years for GPs). Moreover, some continuous trainings deal with this subject but until now health professionals are not obliged to follow these courses. French scientific books on this topic are few. At last, information could be misunderstood.

Health professionals overestimated the teratogenic risk for all drugs included in our questionnaire. Several reasons could explain this misperception. Fear about teratogenicity appeared since thalidomide disaster. This fear has been increased by other events (diethystilbestrol and retinoids) that occurred later and were widely reported by media. GPs and pharmacists are also afraid of litigation. On another hand, it is possible that the mark given graphically on the VAS does not really correspond to the value thought by the participant. Nevertheless, a longer VAS than usually has been chosen to better evaluate small percentages. We also wanted to use the same methodology as a Spanish group ${ }^{8}$ who had performed a similar study including physicians in order to compare our results with theirs for GPs. Moreover, even if the indicated value on the VAS does not correspond to the real perception of the respondent, the difference obtained between the "true" risk and the one estimated is so large that the conclusion remains appropriate.

Thus, for several drugs, we compared our GPs results with those reported in the Spanish study where both women from the general population and physicians (GPs, gynaecologists, students during preclinical and clinical training) had been included. For all these drugs, GPs of Midi-Pyrenees area gave a higher value than the Spanish GPs. This fact could be explained by the difference in the sample size (25 GP in the Spanish study; 103 GP for the present study). By chance, the Spanish group might have included in the survey physicians who had a better teratogenic risk perception. On the other hand, it is possible that Spanish initial training is more consistent on this topic. Indeed, concerning Spanish medical students (during preclinical and clinical training), risk perception declined as they mature. At last, during life work, continual course, information and communication might be better than in France.

Disparities which were observed in responses according to the profession or within the same profession suggest the intervention of external factors besides pharmacological knowledge. Indeed, health professional opinion may be modified by their kind of practice, training, experience, conviction, ethic... This influence of external factors has already been suggested in a study showing significant differences between GPs and pharmacists for medication use. ${ }^{9}$ In the present study, GPs generally gave more clear-cut responses than $\mathrm{CPs}$ that can be explained by the fact that GPs have to decide to prescribe a drug or not in a pregnant woman.

This high perception of teratogenic risk could lead to disadvantageous decisions for pregnant women and her intended infant. Indeed, a pregnant woman with an acute or chronic disease could be treated inadequately causing physiological and psychological pain to herself and to her foetus too. If a drug is used through inadvertence on the first trimester, the woman could ask for pregnancy termination all the more because women rated teratogenic risk significantly higher than health professionals. $^{8,10}$ The fact that CPs perceive a higher risk than it is implies that they cannot counteract the fear that can be induced by the information which was given by the GP to pregnant women.

To face up this misperception of teratogenic risk and to refresh the knowledge on medication risk during pregnancy, the more adequate approach could be education and continuous diffusion of reliable information since Sanz et al. observed that risk perception declines as medical students receive more courses. It is also important to improve the initial and continuous training on this field. Indeed, a more accurate perception of the risk will permit healthcare professionals to give better advice. It has been shown that the tendency to terminate pregnancy significantly decreased after an antenatal consultation about drug exposition. ${ }^{11,12}$ Moreover, counselling can decrease the perception of teratogenic risk by women themselves. ${ }^{13}$ Another point concerns the way the risk is communicated. The ways in which risks are presented can affect the ways in which they are perceived. ${ }^{10,14-16}$ Even if a Canadian study has pointed out the difficulty of changing the opinion despite evidence-based facts ${ }^{\uparrow 4}$, the evaluation of teratogenic risk should be carried on in the future since doubt increases risk perception.

\section{CONCLUSIONS}

Potential teratogenic and foetotoxic risks are not well-known by general practitioners as well as community pharmacists. Health professionals who think that a risk exists, overestimate it. This misperception can lead to inappropriate decisions for pregnancy outcomes. More efforts are needed to sensitize general practitioners and community pharmacists during initial and continuous trainings and to better communicate on teratogenic risk to inform pregnant patients.

\section{ACKNOWLEDGMENTS}

We thank general practitioners and community pharmacists who have participated to the study. 


\section{CONFLICT OF INTEREST}

None declared. No external funding sources

declared.

\section{References}

1. Lacroix I, Damase-Michel C, Lapeyre-Mestre M, Montastruc JL. Prescription of drugs during pregnancy in France. Lancet 2000;256:1735-6.

2. Montastruc JL, Bongard V, Lapeyre-Mestre M. Perception of the risk of gastrointestinal adverse drug reactions with nonsteroidal anti-inflammatory drugs (including coxibs) : differences among general practitioners, gastroenterologists and rheumatologists. Eur J Clin Pharmacol. 2003;59:685-8.

3. Bongard V, Ménard-Taché S, Bagheri H, Kabiri K, Lapeyre-Mestre M, Montastruc JL. Perception of the risk of adverse drug reactions : differences between health professionals and non health professionals. Br J Clin Pharmacol. 2002;54:433-6.

4. Briggs GG, Freeman RK, Yaffe SJ. Drugs in pregnancy and lactation: a reference guide for fetal and neonatal risk, 6th Edition, Lippincott Williams and Wilkins eds, Baltimore, 2002.

5. Reprotox: An information system on environmental hazards to human reproduction and development. The reproductive toxicology center, Bethesda, www.reprotox.org

6. Friedman JM, Polifka JE. Teris: The teratogenic information system. University of Washington, http:apps.medical.washington.edu/teris/

7. Damase-Michel C, Vié C, Lacroix I, Lapeyre-Mestre M, Montastruc JL. Drug counselling in pregnancy: an opinion survey of French community pharmacists. Pharmacoepidemiol Drug Saf. 2004;13:711-5.

8. Sanz E, Gomez-Lopez T, Martinez-Quintas MJ. Perception of teratogenic risk of common medicines. Eur J Obstet Gynecol Reprod Biol. 2001;95:127-31.

9. Bootman JL, Hurd PD, Gaines JA. Physician and pharmacist attitudes toward medication use. Am J Hosp Pharm. 1982; 39:818-21.

10. Pole M, Einarson A, Pairaudeau N, Einarson T, Koren G. Drug Labelling and risk perceptions of teratogenicity : A survey of pregnant canadian women and their health professionals. J Clin Pharmacol. 2000;40:573-7

11. Koren G, Bologa M, Long D, Feldman Y, Shear NH. Perception of teratogenic risk by pregnant women exposed to drugs and chemicals during the first trimester. Am J Obstet Gynecol. 1989;160:1190-4.

12. Koren G, Bologa M, Pastuszak A. Women's perception of teratogenic risk. Can J Public Health 1991;82:S11-4.

13. Mazzota P, Magee LA, Maltepe C, Lifshitz A, Navioz Y, Koren G. The perception of teratogenic risk by women with nausea and vomiting of pregnancy. Reprod Toxicol. 1999;13:313-9.

14. Jasper JD, Goel R, Einarson A, Gallo M, Koren G. Effects of framing on teratogenic risk perception in pregnant women. Lancet 2001;358:1237-8

15. Polifka JE, Faustman EM, Neil N. Weighing the risks and the benefits : a call for the empirical assessment of perceived teratogenic risk. Reprod Toxicol. 1997;11:633-40.

16. Aronson JK. Risk perception in drug therapy : Editors'view. Br J Clin Pharmacol. 2006;62:135-7. 